\title{
Imaginarios geográficos, grupos dominantes e ideas sobre nación. Dos propuestas de transformación territorial para ámbitos fluviales argentinos
}

\author{
Geographical imaginaries, dominant groups and ideas \\ about nation. Two proposals for territorial transformation \\ in argentinian river areas
}

\author{
Gisela Ariana Rausch¹ y Diego Martín Ríos²
}

\begin{abstract}
RESUMEN
Los imaginarios geográficos elaborados por los grupos dominantes han operado históricamente como estrategias para la apropiación territorial. En los ámbitos fluviales, esos imaginarios se sustentaron muchas veces en las ideas de nación, legitimando o intentando impulsar transformaciones a través de la organización tecnológica de la naturaleza, en sintonía con los paradigmas tecnocráticos preponderantes.

Pretendiendo evidenciar la importancia de tales imaginarios en la construcción de una idea específica de nación, progreso y desarrollo en Argentina, se presentan dos casos pertenecientes a dos tramos del río Paraná (las islas del Delta y el tramo medio) en los que esas ideas -vehiculizadas en construcciones imaginarias- se materializaron en iniciativas de transformación de ámbitos fluviales. El análisis realizado ha permitido colocar de relieve las estrategias de apropiación por parte de los grupos de poder, para imponer un modelo de orden territorial de características excluyentes, en función de sus intereses.
\end{abstract}

Palabras clave: imaginarios geográficos- ámbitos fluviales- grupos dominantes- nacióntransformaciones territoriales

\section{ABSTRACT}

Geographical imaginaries produced by dominant elites have historically operated as strategies for territorial appropriation. In river areas, those imaginaries were many times sustained on the ideas of nation, legitimizing or trying to promote territorial transformations (through the technological organization of "nature") in tune with the prevailing technocratic paradigms.

Expecting to highlight the significance of imaginaries in the construction of specific ideas about nation, progress and development in Argentina, we introduce two cases located in two places of Paraná River (the Delta's islands and the central section). In both, the three ideas -mobilized by imaginaries constructions- were materialized in territorial transformation proposals. The analysis has allowed to show the appropriation strategies developed by dominant elites to impose an exclusive model of territorial order, based on their own interests.

Key words: Geographical imageries- river areas- dominant groups- nation- territorial transformation 
Los ámbitos fluviales conforman espacios fecundos para el desarrollo de la imaginación y los imaginarios geográficos. Los elementos constitutivos de estos ámbitos (tanto los flujos de agua como las tierras que los contienen) han sido considerados por los grupos hegemónicos como materiales maleables para la formulación de los más diversos modos de aprovechamiento, usos y propuestas de cambio, acorde a las valoraciones preponderantes en cada momento histórico.

Las construcciones discursivas y las imágenes que estos grupos sociales han difundido, se han materializado, por ejemplo, en obras de infraestructuras (proyectos hidroeléctricos, corredores viales, puentes, canalizaciones, etc.) y en el diseño de nuevas áreas urbanas (zonas comerciales, enclaves de vivienda, áreas verdes, etc.) que procuraron poner un (nuevo) orden a los elementos que constituían dichos ámbitos.

Por otra parte, el agua (en sus formas de ríos, mares, lagunas) ha sido frecuentemente utilizada como símbolo de nacionalismo en la historia del capitalismo y, específicamente, en el proceso de constitución de los estados nacionales (Aboites, 1999; Kaika, 2006; Hanna y Allouche, 2018). Asimismo, la construcción de una idea de nación ha sido una de las estrategias a la que han recurrido de manera frecuente los grupos dominantes, con el objetivo de impulsar transformaciones en los

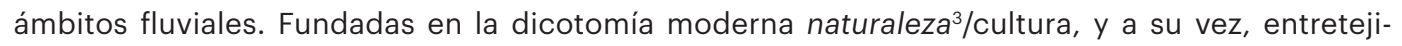
das con los ideales de determinados paradigmas (la modernidad liberal, el desarrollismo), dichas transformaciones han desconsiderado, muchas veces, las formas, propiedades y componentes específicos presentes en los ámbitos fluviales (desde las condiciones naturales propias hasta los grupos sociales locales).

El objetivo que propone el trabajo es dar cuenta acerca del rol estratégico que tuvieron -durante casi dos siglos- las elaboraciones imaginarias de los grupos dominantes de Argentina, en la construcción de una idea específica de nación, progreso y desarrollo para dos ámbitos fluviales del río Paraná. Para ello, el artículo presenta dos casos que tuvieron lugar en distintos momentos históricos y en dos tramos diferentes del río (islas del delta y el tramo medio). En cada uno de ellos, la idea de nación -vehiculizada en discursos e imágenes, y asociada a un paradigma tecnocrático específico- tuvo su materialización en iniciativas particulares de transformación territorial.

Para el abordaje de cada caso, se ha adoptado una estrategia metodológica de tipo cualitativo, sustentada en fuentes literarias, hemerográficas y publicaciones específicas.

El primer caso aborda la construcción de los imaginarios geográficos de las islas del Delta del Paraná a mediados del siglo XIX, en la que las ideas y pensamientos plasmados en las obras Argirópolis (1850) y El Carapachay (1855) de Domingo Faustino Sarmiento han tenido un papel destacado. Los discursos e imágenes literarias presentes en esas obras fueron fundamentales para la creación decimonónica de los imaginarios geográficos (y de la naturaleza) de esa región fluvial. Éstos se sustentaban en las ideas de civilización y de progreso que fueron adoptadas por las elites liberales del siglo XIX, y en las que los cursos de agua eran concebidos como elementos articuladores en la conformación de un nuevo arreglo institucional y de una nueva nación para el

En este artículo se considera que toda dimensión "natural" está atravesada y construida (material y simbólicamente) por la dimensión social-cultural. Lo que se reconoce bajo el término naturaleza posee una condición problemática e híbrida, constituyendo un significado inestable. Problematizaciones sobre el concepto pueden verse en: Smith (1990); Swyngedouw (2011); Castree (2014). 
país (superadores de la Confederación Argentina ${ }^{4}$ ). Además de efectuar un análisis de contenido de las obras mencionadas, se utilizan otras fuentes secundarias en las que otros autores han reflexionado sobre las propuestas e ideas presentes en el imaginario sarmientino.

El segundo caso aborda un momento en el proceso de formulación del proyecto hidroeléctrico Paraná Medio (PHPM). Se concibe esta infraestructura como núcleo condensador de ideas en torno a la nación, el territorio nacional y los recursos naturales, que sustentaron el imaginario desarrollista de una fracción del gobierno dictatorial entre 1976 y $1981^{5}$. El análisis de las elaboraciones imaginarias en torno al emprendimiento hidroeléctrico pretende, por un lado, dar cuenta de los modos particulares en que los imaginarios se cristalizan en artefactos tecnológicos y, por el otro, evidenciar cómo tales artefactos impulsaron imaginarios y fantasías en la construcción de una idea específica de nación. Se analizan una serie de conferencias realizadas en 1978 y 1979 en las ciudades de Santa Fe y Paraná respectivamente, en las que participaron diversas figuras públicas y académicas, complementado con fuentes hemerográficas y documentos técnicos del proyecto.

El primer apartado realiza una breve aproximación teórica a los distintos conceptos de imaginarios elaborados por algunos autores, enfocando específicamente en los imaginarios geográficos que, vinculados a la idea de nación, han sido utilizados como estrategias de apropiación y transformación de los ámbitos fluviales por parte de los grupos dominantes. En el segundo y tercer apartado se desarrollan los análisis de los casos mencionados respectivamente, para concluir en el cuarto apartado.

\section{Imaginarios geográficos, grupos dominantes e ideas sobre nación}

En un sentido amplio, puede decirse que los estudios sobre imaginarios, en las diferentes disciplinas dentro de las ciencias sociales, han abordado las elaboraciones de imágenes mentales que las sociedades (y los individuos) construyen como mecanismo de apropiación y aprehensión de la realidad (Bachelard, 1965; Durand, 1981; Castoriadis, 2007;).

Autores más recientes han abordado la temática desde distintas perspectivas, resaltando las diversas formas en que éstos se construyen y funcionan. Así por ejemplo, Agudelo ha destacado el carácter "colonizador" que tiene lo imaginario sobre la realidad, donde la misma es "re-creada" a través de la acción imaginante (la imaginación), y lo imaginario "se conecta con la fantasía para instaurar una gramática connatural a los sujetos y a la sociedad" (Agudelo, 2011:13).

Las Provincias Unidas del Río de la Plata, pasan a denominarse como Confederación Argentina entre 1835 y 1852 . En ese arreglo institucional, las provincias mantenían su gobierno, pero delegaban en la Provincia de Buenos Aires, gobernada por Juan Manuel de Rosas, tanto las relaciones internacionales como la recaudación de impuestos aduaneros, con motivo de que el puerto de Buenos Aires era la única entrada y salida comercial ultramarina.

Se adopta la tesis de Canelo (2016) quien demuestra la conformación heterogénea de la última dictadura militar, consistente en tres facciones con ideas diferentes, aunadas por el consenso antisubversivo, es decir, por el plan de exterminación de la disidencia política. El PHPM puede considerarse una propuesta del ala dura del gobierno, con ideas desarrollistas y nacionalistas. 
Hiernaux (2007:20), por su parte, ha señalado que "en la formación del imaginario se ubica nuestra percepción transformada en representaciones a través de la imaginación, proceso por el cual la representación sufre una transformación simbólica. El imaginario es justamente la capacidad que tenemos, de llevar esta transformación a buen término". Para este autor lo imaginario implicaría el proceso de producción de representaciones acerca de la realidad.

En particular, los imaginarios geográficos circunscriben su interés a las relaciones que se juegan entre las elaboraciones mentales y los mecanismos específicos de apropiación espacial. Hace ya algunos años, Hiernaux y Lindón (2012) señalaban que la incorporación de los estudios sobre subjetividad a la Geografía Humana constituía un desafío por la tradición misma de la disciplina, sustentada -según los autores- en presupuestos teórico-metodológicos simplistas y únicamente orientados a lo material 6 . De este modo, los estudios que han indagado en las tramas de sentido que conforman los imaginarios han contribuido a instalar nuevos interrogantes y temas en la disciplina, incluso a una renovación de los objetos de estudio, asumiendo "que el espacio no se reduce a la simple materialidad" (Hiernaux y Lindón, 2012:15). En este sentido, los autores han señalado que en los imaginarios geográficos se articulan imágenes y palabras, figuraciones y discursos que le otorgan una trama de sentidos a las acciones que participan de la construcción, transformación y cambios del espacio. Los seres humanos pensamos y reflexionamos con imágenes y con palabras, es decir que los procesos de percepción y procesamiento mental del espacio son los que nos permiten elaborar imágenes mentales sobre ellos. Al mismo tiempo, las imágenes mentales se convierten o corporizan en expresiones gráficas (cartografías, planos, fotografías, publicidades gráficas, dibujos, pinturas, etc.), las cuales son figuraciones en las que se condensa el imaginario. Sin embargo, este último claramente las desborda y supera. Sobre esta imbricada articulación entre imágenes y palabras, Debarbieux (2012) agrega que, "la función figurativa y emblemática de la imagen -la imagen otorga figura a una realidad de otra naturaleza, diferente a la suya y se convierte en su representante- se acopla perfectamente con la función narrativa y argumentativa del discurso, que establece su justificación" (Debarbieux, 2012:149).

En otra obra, Hiernaux y Lindón (2007) consideran que si bien la producción de imaginarios tiene claras implicancias en las intervenciones materiales concretadas en el espacio, también esas mutaciones materiales repercuten en la gestación y readaptación de los propios imaginarios. De ahí que para estos autores (Hiernaux y Lindón, 2012), uno de los retos de la Geografía Humana contemporánea -así como de otras disciplinas que abordan la dimensión espacial/territorial- es el de avanzar en el conocimiento de la articulación entre los imaginarios geográficos y las formas espaciales.

A su vez, Mondada (2006) ha analizado las relaciones entre los discursos y el espacio, señalando que este último no constituye sólo un objeto de discurso, sino que también es "el lugar a partir del cual se habla" (Mondada, 2006:436). Destaca en tal sentido, que la perspectiva constructivista dentro de las ciencias sociales ha posibilitado asignarle un lugar significativo a la materialidad de las descripciones, las figuraciones y las representaciones del espacio, en el proceso de construcción espacial. De este modo, dice la autora, una visión del espacio no sería determinada ni por el lenguaje ni por la acción, sino elaborada en la mutua recepción de ambos "en virtud de sus fina-

Los autores hacen referencia a una ortodoxia conceptual y analítica consistente en la simple descripción o enumeración, que no abre posibilidades al ejercicio interpretativo. 
lidades prácticas: la descripción configura el espacio que describe, pero ajustándose al contexto en el cual se ve enunciada (...) el espacio no preexiste como tal a la descripción que lo modela: es plásticamente organizado por esta descripción aún cuando ésta es producida en el mismo lugar descrito" (Mondada, 2006:456).

Quienes conservan mayor injerencia en la construcción de los imaginarios geográficos, teniendo la capacidad de imponer sus ideas y subjetividades sobre el resto de la sociedad, son las elites o grupos dominantes. Losada (2016) considera que estos grupos sociales ocupan las posiciones socialmente más encumbradas, producto de que sus integrantes cumplen, por lo menos, con tres atributos esenciales: fortuna económica, poder político y ascendencia cultural. Las influencias de las elites sobre cómo pensar y qué hacer con determinadas áreas geográficas se reflejan por lo general en los discursos, los proyectos, las acciones de los decisores políticos y de los cuerpos técnicos del estado encargados en desarrollar políticas públicas para con esas áreas. También las influencias de los grupos dominantes se manifiestan en las valoraciones/sensibilidades estéticas y culturales sobre cómo concebir, representar y apropiar a esos espacios. La difusión de los imaginarios geográficos de las elites se efectúa a través de distintos mecanismos, tales como las figuraciones, esto es, aquellas imágenes difundidas por las artes gráficas, las imágenes literarias, y diversos tipos de discursos, los cuales participan en la trama de sentido que conforman a esos imaginarios (Hiernaux, 2007).

Entre los muy diversos tópicos que ha encontrado la acción imaginante y los estudios sobre la misma, el de la elaboración de ideas e imágenes en torno a la cuestión nacional por parte de los grupos dominantes, ha sido de especial fertilidad. Los imaginarios sobre la nación pueden localizarse, tanto en la construcción consensuada de una determinada "identidad nacional", sustentada en "ficciones fundacionales" (Bhabha, 2000:216), como en el ejercicio de apropiación territorial que han llevado adelante los distintos estados nacionales.

Una cuestión que destaca Fernández Bravo (2000) es el papel central que han tenido los intelectuales en la articulación del vínculo entre cultura y nacionalismo, así como también el valor que ha tenido la lengua en la construcción de "Io nacional". En un sentido similar, Bhikhu Parekh (2000) ha analizado las teorías nacionalistas del estado y las articulaciones entre construcción estatal y nacional, destacando que para dichas teorías, el estado debía constituirse como nación, es decir, "ser culturalmente y lingüísticamente homogéneo, solidario, como una familia espiritual extendida, protector del modo colectivo de vida y establecido en su propio territorio" (Parekh, 2000:101). Es en este proceso de construcción de "lo nacional", donde la producción de imaginarios adquiere relieve, e incluso, valor instrumental en algunos sectores de poder. Esto se vuelve particularmente notorio, dice el autor, en aquellos casos donde el estado ha buscado "volverse nación" (Parekh, 2000:105), es decir, cuando un grupo social heterogéneo organizado en torno a la forma estatal, ha intentado definirse como nación, y para ello, se propone "moldear" a sus miembros en base a la imagen de ella. Es en estos casos cuando la cuestión cultural se vuelve un instrumento clave al servicio de los grupos dominantes y de la voluntad de homogeneización que los mueve.

En los procesos de construcción de los nuevos estados nacionales en América Latina a cargo de las elites, las poblaciones con las que se contaba, en general, fueron consideradas insuficientes, impropias, "incivilizadas". Así, la promoción de la inmigración europea fue una de las medidas 
más significativas para contrarrestar dicha limitación. Por el contrario, el territorio ofició como el principal elemento aglutinante, priorizándose la consolidación de los estados nacionales a partir de la incorporación de los vastos "fondos territoriales" heredados de la etapa colonial, con el fin de hacerles llegar los beneficios del progreso y de la civilización a esas áreas concebidas como un espacio atrasado, hostil y bárbaro (Moraes, en Zusman 2015).

Siguiendo las interpretaciones de la geografía postcolonial -siendo fuente de inspiración, por ejemplo, las obras de Orientalismo de E. Said y de Geographical Imaginations de D. Gregory- puede decirse que la construcción de los imaginarios geográficos -como los señalados- han sido funcionales en las acciones de dominación y sometimiento de otras formas de organización política, económica y social (por ejemplo, de las poblaciones indígenas o campesinas). Dichos imaginarios asociados a las ideas de espacio vacío, de tierra hostil o infértil, posibilitaron la incorporación de esas áreas a las lógicas (capitalistas) de los países en formación, invisibilizando a sus efectivos ocupantes (Zusman, 2013).

Para el caso de Argentina, por ejemplo, durante el proceso de formación del estado, las ideas de desierto, civilización y progreso, y el imaginario geográfico construido en torno a las mismas, constituyeron el sustento simbólico sobre el cual las élites llevaron adelante el proyecto de estado-nación (Zusman, 2000). Dicho proyecto se materializó en las acciones militares de apropiación de los territorios que hasta ese momento se encontraban ocupados por poblaciones indígenas (en el Gran Chaco y la Patagonia). Como ha destacado la autora, "la metáfora del desierto permitió el ejercicio nominal de la dominación del área" (Zusman, 2000: 63), es decir, se inventó un desierto pasible de ocupación. En el mismo sentido, Rodríguez (2010:14) señaló que esta idea de desierto ha funcionado "como una suerte de artefacto discursivo que provee las imágenes en torno a las cuales se hace, se deshace y se rehace el sentido vacío de lo argentino".

A partir de finales del siglo XIX y a lo largo del siglo XX, las elites nacionales -tanto en Argentina como en el resto de América Latina- fueron suplantando la idea de civilización por la de modernización. Esta última idea apareció frecuentemente en los discursos estatales vinculada a la idea de "desarrollo nacional", y asociada no tanto a la mejora de las condiciones de vida de la población, sino más bien a la dotación de equipamientos e infraestructuras (autopistas, represas, plantas energéticas, etc.). Al igual que en gran parte del siglo XIX, el espacio en su dimensión territorial se convirtió nuevamente en el principal referente para los grupos dominantes, dejándole al pueblo un papel claramente secundario (Moraes, en Zusman 2015).

Dentro de los imaginarios geográficos, los imaginarios de la naturaleza han tenido un papel destacado. Para Debarbieux (2012), uno de los expertos en el tema, los imaginarios de la naturaleza han estado tanto al servicio de los relatos de la civilización como de los procesos de diferenciación, adquiriendo una gran participación en momentos de conformación de los imaginarios nacionales del siglo XIX. Para este autor dicha participación puede identificarse a través de dos formas: la nacionalización de la naturaleza y la naturalización de la nación. En el primero caso, se observa que la base natural se convierte en un emblema, en un símbolo (de pertenencia) de la nación misma (Suiza se convirtió en algo propio de los Alpes; Escocia es algo propio de sus Highlands, etc.). El segundo caso se evidencia cuando operan relatos que establecen una vinculación consustancial entre la base natural y la nación misma, adoptando muchas veces una forma determinista que se expresa, por ejemplo, cuando se alega que el temperamento nacional sumerge sus raíces en determinadas condiciones climáticas, edáficas, topográficas, etcétera. 
Los imaginarios de la naturaleza, sostiene Debarbieux (2012), contribuyen a configurar la superficie de la tierra y ello cobra mayor expresividad a partir de la Modernidad, donde se consolida una voluntad de establecer una demarcación con respecto a la naturaleza a través del ordenamiento del espacio. El ejercicio de esa voluntad implicó antagonizar con la naturaleza objetivada, procurando su orden para orientarla a las necesidades humanas, tanto cognitivas como prácticas. En la modalidad cognitiva (y figurativa) de ordenamiento, la idea de naturaleza está presente en sitios específicos y funciona como contrapunto de la ciudad y lo urbano. Esto ha sido muy bien representado en el caso de las imágenes pictóricas del wilderness norteamericano en el siglo XIX. La modalidad práctica, por su parte, implica poner en orden la naturaleza, como puede ser el establecimiento de un Área Natural Protegida o el diseño de los grandes parques públicos urbanos. De ahí la consideración que realiza Debarbieux (2012:154): “... el ordenamiento de la naturaleza merece también pensarse como imaginario".

Así por ejemplo, en Argentina, las elites nacionales encargadas de la "construcción del país" adoptaron una mirada predominantemente porteña ${ }^{7}$ y pampeana a partir de la cual concibieron a las demás áreas geográficas como un otro geográfico, esto es, en palabras de Moraes (2003), la construcción de una imagen espacial en la que predomina una carga valorativa negativa tanto en los aspectos físicos como sociales. Así, esas otras áreas geográficas fueron ubicadas, con frecuencia, entre las posiciones menos agraciadas dentro del repertorio territorial en conformación. No obstante ello, el imperio del progreso y la misión civilizatoria, asociados con el avance de la razón y del conocimiento científico, junto a las redes del comercio y la nueva configuración económica mundial, terminaron por convertir algunos elementos de la naturaleza presentes en esas otras áreas geográficas en recursos naturales. A menudo, estos recursos fueron explotados hasta su degradación o extraídos hasta su aniquilación, mientras que sus habitantes fueron vistos como incivilizados, con el consecuente desplazamiento y usurpación de sus tierras (incluso, en algunos casos, exterminando sus gentes, culturas y formas de vida) (Serje, 2017).

\section{Sarmiento, las islas del Delta y el imaginario geográfico fluvial como proyecto nacional}

El agua es uno de los elementos de la naturaleza que las sociedades han tratado de doblegar con mayor empeño a lo largo del devenir histórico (Worster, 2011). Al mismo tiempo, dicha dominación ha sido colocada como un factor de importancia en la construcción del sentido de "lo nacional", utilizado por una gran variedad de estados e imperios en distintos contextos espacio-temporales.

En la Antigua China, por ejemplo, el manejo de las aguas ha tenido una marcada participación en su identidad nacional. Allí los gobernantes, más allá de apoyarse en las filosofías del confusionismo o del taoísmo, han aprendido tempranamente una lección esencial todavía vigente: “Si se quiere ganar y mantener el poder sobre las personas, debes ganar y mantener el poder sobre el entorno natural" (Worster, 2011:7). Someter los flujos "salvajes" del agua con el fin de controlar a los pueblos, ha implicado la defensa de sus habitantes ante los efectos destructivos de las inundaciones; irrigar sus tierras secas; mitigar las sequías que arruinan sus cultivos y ganados, 
y convertir los cursos de agua en vías navegables para facilitar el transporte y la comunicación. Claramente, este última funcionalidad ha sido central para la consolidación de un imperio que buscaba articular una región húmeda y productora de alimentos, ubicada al sur, con una región semiárida donde se hallaba el poder político en la ciudad de Beijing, localizada a más de 1600 kilómetros hacia el norte. El Gran Canal consistió en una monumental obra hidráulica (iniciada en 458 A.C y terminada alrededor del 1300. D.C) que le permitió al imperio, por un lado, la obtención de alimentos, el cobro de impuestos y reclutamiento de una gran cantidad de fuerza de trabajo y, por otro, la consolidación del sometimiento de una nación sobre otras a partir de control técnico de las aguas (Worster, 2011), con implicancias en la construcción del imaginario geográfico en función de los intereses y los proyectos de las elites gobernantes.

Los Estados Unidos, por su parte, fundaron su poderío económico a partir de la expansión de las comunicaciones y del transporte, alcanzando un fuerte impulso durante el lapso comprendido entre su independencia en $1776^{8}$ y la primera mitad del siglo XIX. Con las obras de canalización de los ríos (junto a los ferrocarriles y el telégrafo), la Unión procuró la conformación de una red interconectada, por un lado, para la creación de un mercado interno y de exportación, y por el otro, para la incorporación de nuevas tierras productivas (correspondientes con ecosistemas diversos) junto al poblamiento, primero, hacia el medio oeste $y$, luego, hacia el lejano oeste, que fue liderado por inmigrantes europeos llegados a las ciudades de la costa noreste (primordialmente Nueva York). Remontando el río Hudson desde la indicada ciudad se buscó una vinculación navegable con la región de los Grandes Lagos para lo que se terminó construyendo el canal Erie, abriéndose paso a la expansión y el progreso hacia el medio oeste (Finch, 1925; Worster, 2011). Ese carácter territorial expansivo, que trajo consigo la dominación y la transformación de la naturaleza, ha impregnado el imaginario geográfico estadounidense (aún presente en nuestros días), el cual ha sido tomado como modelo civilizatorio por varios estados-nacionales en conformación.

En Europa las canalizaciones de los ríos estuvieron asociadas con la primera revolución industrial en Inglaterra, Holanda y Francia, con las que se procuró ampliar las vías de transporte fluviales para incrementar los circuitos de producción y consumo. A partir de la segunda mitad del siglo XIX, la Francia del II Imperio de Napoleón III -afirmada en las ideas del progreso tecnocrático y científico que promovió el saintsimonismo (1825)- tomó la delantera respecto de este tema, propagándose la construcción de canales por distintas regiones del país, así como también por el extranjero. Entre los difusores franceses que adscribieron a esa ideología y que alcanzaron mayor repercusión internacional se destacó el ingeniero Ferdinand de Lesseps, quien dirigió la construcción del canal de Suez (1869) para unir el Mar Rojo y el Mar Mediterráneo, y quien también estuvo a cargo, dos décadas más tarde, de las obras del canal de Panamá para vincular los océanos Pacífico y Atlántico, las cuales no lograron terminarse ${ }^{9}$.

En Argentina, las elites "nacionales"10 que lideraron la agitada conformación del estado durante el siglo XIX, adoptaron, generalmente, una fe encomiable en las ideas de progreso, en el

Según los escritores de los primeros tiempos de la nación estadounidense, el propio George Washington, en tanto topógrafo e ingeniero, antes que ser considerado un soldado y un estadista, fue aclamado como el padre de los canales de ese país (Finch, 1925).

9 Luego de la quiebra de la empresa francesa a cargo de las obras (cuyo director era el ingeniero Lesseps) el Canal de Panamá fue finalizado por capitales estadounidenses en 1914.

10 Las llamadas elites "nacionales" o "porteñas" - por su residencia principal en la ciudad de Buenos Aires- recién adquirieron un nivel de consolidación mayor a fines del siglo XIX. Entre 1852, con la caída de Juan Manuel de Rosas, y 1880, con el ascenso del Julio Argentino Roca, 
papel de la inmigración europea, en las comunicaciones y en el dominio humano sobre la naturaleza, teniendo como referentes las transformaciones materiales alcanzadas en la Europa industrial (asociadas con la primera y segunda revolución) y en los Estados Unidos. En ese contexto, las canalizaciones -justificadas por la difusión de las ideas saintsimonianas- fueron comprendidas como baluartes del progreso (Silvestri, 2003) y como garantía para alcanzar la civilización en los territorios desérticos, nutriendo los imaginarios geográficos que esas mismas elites delineaban.

La libre navegación de los ríos interiores se hallaba en el centro de las discusiones sobre las dimensiones políticas, económicas e institucionales de la Confederación Argentina hacia mediados del siglo XIX, por lo que la geografía fluvial se tornó en un territorio fértil para la imaginación de algunos de los líderes intelectuales y políticos que asumieron una gravitación destacada dentro de las elites dirigentes. Juan Bautista Alberdi, proveniente de una familia tucumana tradicional, fue uno de los líderes que con sus propuestas imaginarias postularon, desde su exilio en Chile, un arreglo institucional en el que se planteaba otro orden fluvial, quitándole prominencia a la provincia y ciudad de Buenos Aires donde residía la Aduana y principal puerto del país. En Bases y puntos de partida para la organización política de la República Argentina, la más reconocida obra de Alberdi escrita en el año 1852, es posible hallar varios argumentos al respecto de las vinculaciones entre libertad de comercio y libertad de navegación, tal como se evidencia en este párrafo: "Los grandes ríos, esos caminos que andan, como decía Pascal, son otro medio de internar la acción civilizadora de Europa por la imaginación de sus habitantes en lo interior de nuestro continente. Pero los ríos que no se navegan son como si no existieran. Hacerlos del dominio exclusivo de nuestras banderas indigentes y pobres, es como tenerlos sin navegación. Para que ellos cumplan el destino que han recibido de Dios, poblando el interior del continente, es necesario entregarlos a la ley de los mares, es decir, a la libertad absoluta. Dios no los ha hecho grandes como mares mediterráneos, para que sólo se naveguen por una familia" (Alberdi, 2017:106).

Si bien las ideas de un teórico de lo práctico como fue Alberdi (Sánchez Sorondo, 1977) han alcanzado gran trascendencia (muchas de ellas se vieron plasmadas en la Constitución de 1853), quien ha aportado mayor contenido a la conformación de un imaginario geográfico de corte fluvial para el país fue Domingo Faustino Sarmiento. A pesar de provenir de una provincia periférica (San Juan) y de una familia humilde, Sarmiento consiguió insertarse dentro de los círculos de poder porteños y llegar al cargo de Presidente de la Nación (1868-1874), además de ocupar otras responsabilidades de importancia (senador, gobernador, ministro, etc.). Las ideas y pensamientos de Sarmiento lograron obtener gran visibilidad y trascendencia debido a su extraordinaria habilidad como escritor y periodista, además de su acérrima oposición a Juan Manuel de Rosas. A causa de ello, se exilió en Chile (1841-1851) donde desarrolló parte de sus obras más importantes y su labor como periodista (Losada, 2016). Su experiencia como docente le permitió estar a cargo de la formación de profesores (Escuela Normal) en Santiago de Chile, donde fue invitado por el Ministro Manuel Montt para realizar un extenso viaje por Europa, África y América, con el objetivo de asesorarse del sistema educativo logrado en los "países más civilizados". Esos viajes resulta-

gran parte de esas elites se hallaban atravesadas por enfrentamientos políticos y militares. Con la llamada "Generación del Ochenta" estos grupos alcanzan mayor integración y convivencia social, siendo un factor clave la aglutinación política obtenida con el Partido Autonomista Nacional; coalición política que logró doblegar las tensiones internas y gobernar el país durante poco más de treinta años con un marcado perfil conservador y liberal. Dentro de las familias de las elites la presencia de terratenientes bonaerenses y de otras provincias del interior era predominante, tornándose un poco más heterogénea hacia finales del siglo XIX con la llegada de inmigrantes y con la activación de las actividades industriales (Losada 2016). 
ron de gran inspiración para el desarrollo de las ideas que el líder sanjuanino pensó para el país durante su exilio (Zusman, 2006).

Dentro del ámbito fluvial, las singularidades de las condiciones naturales presentes en el intrincado sistema de islas del Delta del Paraná, próximo al área de influencia de la ciudad de Buenos Aires, tales como la gran cantidad de vías navegables, el reparo para las embarcaciones en momentos de tormentas o la abundancia de forestación siempre verde (aspectos diferenciales respecto del paisaje pampeano predominante en los alrededores), han sido un factor de gran atracción para la imaginación y la construcción de imaginarios geográficos, de los que Sarmiento fue uno de los principales libretistas durante la segunda parte del siglo XIX. La transformación de la Nación Argentina, la necesidad de sustitución de su población, de efectuar obras para la comunicación y el transporte (como es el caso de la adaptación de cursos de agua en vías navegables), asociadas junto a las ideas de progreso y de civilización, fueron las principales tramas de sentidos que hilvanaron esos imaginarios geográficos en clave fluvial pensados por Sarmiento para las islas del Delta y otros importantes cursos de agua.

En este apartado se propone abordar algunas de las ideas/pensamientos/propuestas de Sarmiento que nutrieron de manera sustancial la construcción del imaginario geográfico (y de la naturaleza) de la región del Delta del Paraná entre las décadas de 1850 y 1880 . Para ello se ha analizado un conjunto de discursos e imágenes literarias presentes en las obras Argirópolis (1850) y El Carapachay (1855); obras en las que el autor proponía la imperiosa movilización de la geografía fluvial isleña para alcanzar los designios del progreso y la civilización.

\section{La imaginación de Sarmiento y la puesta en movimiento de las islas del Delta}

Sin conocer las islas de manera presencial, Sarmiento advertía en las cartografías existentes y en los conocimientos a los que accedía sobre la región, las posibilidades imaginarias que el intrincado sistema deltaico, ubicado a las puertas del Río de la Plata y de la ciudad de Buenos Aires, podían ofrecer. Para Pickenhayn (2000), la presencia de la trama geográfica en las ideas y propuestas de este controversial líder del siglo XIX son por demás significativas; en su obra Facundo: civilización y barbarie, esa trama aparece en las descripciones del desierto y en las contraposiciones entre la ciudad (lo civilizado) y el campo (lo bárbaro), y vuelve a develarse en sus obras Argirópolis y El Carapachay, donde se ocupa de las islas del Delta del Paraná.

En pos de solucionar los conflictos y desequilibrios entre los distintos estados que conformaban la Confederación Argentina hacia mediados del siglo XIX, al final del período Rosista y bajo bloqueo anglo-francés, Sarmiento imaginaba desde su exilio en Chile un arreglo institucional distinto a través de su obra Argirópolis. A la nueva conformación institucional la denominó Estados Unidos del Río de la Plata y propuso que se sumaran a ella los estados del Paraguay y del Uruguay, por sus vinculaciones histórico-geográficas con la Confederación y la cuenca del Plata, y por la necesidad de que todas ellas se aglomerasen en una sola nación, tal como venía sucediendo con las "naciones más civilizadas" de esos tiempos (Alemania, Estados Unidos, etc.). Sarmiento esbozó en este escrito una utopía geográfica en la que la isla Martín García, ubicada estratégicamente en la desembocadura que tienen los grandes ríos Paraná y Uruguay sobre el Río de la Plata, ocu- 
paría un papel crucial creándose en ella la capital de la Unión (la Ciudad del Plata-Argirópolis)"1, en donde deberían residir el Congreso, la Aduana Nacional, el Servicio Topográfico, entre otras instituciones republicanas.

Para alcanzar este proyecto utópico, pero con inflexiones de realidad ${ }^{12}$ (Amaro Castro, 2003), Sarmiento propone superar los obstáculos que le impone la geografía de la Argentina: "Si se consulta el mapa geográfico de la República Argentina, se notará que es casi sin excepción de país alguno de la tierra, el más ruinosamente organizado para la distribución proporcional de la riqueza, el poder y la civilización por todas las provincias confederadas. Al oeste las escarpadas cordilleras de los Andes, que embarazan la inmediata comunicación con el Pacífico... al sur... la actual confederación Argentina... sufre las devastaciones de los salvajes. (...) Por el norte, el desierto por una parte y las provincias del sur de Bolivia, escasas en productos lucrativos. (...) Por el este, en fin, el más envidiable sistema de ríos cerrados al comercio extranjero, y en un ángulo extremo de ese inmenso territorio..., un sólo puerto, en Buenos Aires" (Sarmiento, 2011:79-80). Esas limitaciones eran producto de la geografía física, de la impericia de sus gobernantes y de la ausencia en las comunicaciones, según sostiene Natalio Botana (2011). Para este sanjuanino de talento poco común para la época, era prioritario poner en acción a las grandes arterias fluviales de comunicación para lograr el crecimiento comercial e industrial, la creación de nuevas ciudades portuarias y la radicación de grandes cantidades de inmigrantes europeos a quienes debía facilitarse la propiedad agrícola; en fin, todos aquellos procesos que este líder consideraba ineludibles para alcanzar el progreso de la nación y lograr vencer la "inmensa herencia desierta" del pasado.

A través de esta propuesta, el "profeta de las pampas" -tal como lo llamaba Ricardo Rojas- imaginaba que la nación debía adquirir una mayor "impronta fluvial", esto es, una "sociedad echada en el agua", para lo que resultaba imperioso liberar la navegación de los ríos interiores y aprovechar el complejo sistema del Plata, tornando navegables no sólo a las grandes arterias fluviales (el Paraná, el Uruguay, etc.), sino que además proponía canalizar el río Tercero y así llegar con el comercio a la provincia de Córdoba y, lo mismo para el caso del río Bermejo y la posibilidad de acceso fluvial a las provincias del noroeste (Salta y Jujuy) ${ }^{13}$.

En ese imaginario donde la geografía de carácter fluvial daba un paso hacia adelante, la navegación debía constituirse en: "el punto culminante de las atribuciones del Congreso, dado que, cuando el mar no baña nuestro territorio sino por un extremo, la voluntad humana podrá prolongar hacia el interior por medio de los ríos que son extensos como los mares, la comunicación y el

Habiendo tomado nota de lo sucedido con los Estados Unidos de Norteamérica y la creación de su ciudad capital, Washington, en pos de restarle poder a la ciudad de Nueva York, Sarmiento proponía una decisión homóloga con la creación de la nueva capital de los Estados Unidos del Rio de la Plata, la Ciudad del Plata, quitándole prominencia a la ciudad portuaria (y aduanera) de Buenos Aires.

12 Entre esas inflexiones de realidad se destaca el diálogo que han alcanzado las ideas vertidas en Argirópolis respecto de la libre navegación de los ríos interiores o del papel central que debía dársele a la inmigración europea; ideas que fueron retomadas, por ejemplo, en la obra Bases de Juan Bautista Alberdi de 1852. Asimismo, por otro lado, en varios tramos de su propuesta, Sarmiento resaltaba la condición fluvial excepcional que tenía Entre Ríos, por lo que le cabía un papel central dentro de ese nuevo arreglo institucional, señalando de manera indirecta el protagonismo que debía ocupar el caudillo entrerriano, Justo José de Urquiza, para poder alcanzar esa nueva organización política. En menos de dos años, este último caudillo lideró la batalla de Caseros con la que dio caída (momentánea) al poder de Buenos Aires representado en la figura de Juan Manuel de Rosas.

13 Hacia el final del período colonial, el Virrey de Sobremonte, restableció un antiguo proyecto español: canalizar el río Tercero y acercar los "Andes al Paraná". Luego, en los primeros años del gobierno Patrio, el Coronel Pedro Andrés García escribió, en 1813, un libro titulado Memoria sobre la navegación el río Tercero y otros ríos que confluyen al Paraná. 
contacto directo con el comercio extranjero (...). El Congreso, en fin, dirá si el Río de la Plata será el hijo predilecto de la Confederación" (Sarmiento, 2011:86). Para el líder sanjuanino, el sistema fluvial con eje en el Plata debía ocupar un lugar de centralidad en la reconstrucción del imaginario de la nación. Así, en la propuesta sarmientina operaría una suerte de desplazamiento respecto de la idea de la nacionalización de la naturaleza -al decir de Debarbieux (2012)-, en donde los paisajes típicamente pampeanos deberían cederle lugar a los paisajes fluviales que, por su propia condición de mayor accesibilidad, los consideraba más apropiados para su incorporación a los mercados europeos y la gestación de los nacionales.

Este imaginario geográfico en clave fluvial asociado con el movimiento -o con los paisajes en movimiento al decir de Zusman (2006)-, remitía a las experiencias y conocimientos que el autor de la obra Facundo había adquirido en sus viajes por los Estados Unidos en 1847. Más que en Europa, Sarmiento hallaba en la experiencia estadounidense un modelo de transformación territorial e institucional aplicable para la Argentina por las similitudes que ésta mantenía respecto del país del norte: grandes extensiones y espacios desérticos, población originaria escasa e incivilizada, condiciones ventajosas para el recibimiento de inmigrantes europeos, procesos de expansión territorial, etc. Entre las rápidas mutaciones del paisaje yanqui, ocurridas durante la primera mitad del siglo XIX, los avances y las inversiones en las comunicaciones (telégrafo) y en los transportes (como los canales navegables y los ferrocarriles) fueron los que más sorprendieron a Sarmiento; en varios párrafos de Argirópolis son resaltadas las redes de canales construidas entre las distintas cuencas de ese país de norte, facilitando el comercio tanto entre los estados de la Unión como con Europa.

Unos años después, en septiembre de 1855, Sarmiento realizó su primer reconocimiento presencial de navegación por la zona del Bajo Delta, esto es el sector de islas más próximo al Plata y a los pueblos Las Conchas y San Fernando. Al año siguiente, en una de las islas establece su "casa de campo", convirtiéndose el paisaje isleño en uno de sus predilectos, justamente, para quien, por contraposición, provenía de los paisajes más áridos del país. Sus impresiones, pensamientos e ideas sobre qué hacer con esta región del Delta paranaense, fueron publicadas en el Diario El Nacional en su artículo "El Carapachay" (12 de diciembre de 1857), el que junto a otras publicaciones en periódicos, terminaron siendo recopiladas en formato de libro bajo ese mismo nombre. En esa publicación, Sarmiento relataba su experiencia de viaje, los contactos con la naturaleza isleña, las posibilidades productivas que allí podrían efectuarse a causa de la gran fertilidad de los suelos y la abundancia de agua o el tipo de cultivos que deberían plantarse en las islas (como es la incorporación del mimbre traído y cultivado por él). Esas primeras descripciones, sostiene Ruíz Moreno de Bunge (2004), convirtieron a Sarmiento en uno de los principales "inventores" del Delta; labor que él mismo se adjudicaba por ese entonces, nada extraño para un escritor por demás autorreferencial: "aquí existía el Carapachayo sin que hubiera Carapachay, que nosotros hemos tenido que inventar, ya que nos ha cabido el honor de ser el primer Herodoto que describa estas afortunadas comarcas" (Sarmiento, 1974: 26). En una carta dirigida a su hijo adoptivo Domingo Fidel ("Dominguito"), Sarmiento se expresaba sobre las potencialidades del Delta haciendo alusión al imaginario de la tierra prometida llena de oportunidades, tomando como referencia la fiebre de oro de la California estadounidense durante las décadas de 1840 y 1850: "... un paraíso terrenal, una California que he descubierto yo, aunque todos conocían y algunos vivían en ella... pero éste es el resultado del estudio y del hábito de ver las cosas con los ojos de la inteligencia. Voy hacer una Venecia gigantesca, y toda la emigración irá a establecerse en el Archipiélago del Plata y Paraná" (Ruiz Moreno de Bunge, 2004:41). 
El progreso de la región deltaica sólo podía lograrse, según el pensamiento de Sarmiento, a través de la descripción y el conocimiento erudito de la Ciencia, así como por medio de la transformación que brindaban las técnicas y la incorporación de capitales y de trabajo, preferentemente inmigrante (y europeo). Para el autor de la obra El Carapachay, los habitantes autóctonos (los carapachayos, nombre guaranítico que remitía a los pobladores del Delta), no constituían material suficiente para avanzar prontamente hacia el camino de la civilización y del progreso del país; su escaso número de habitantes así como su insuficiente ingenio y laboriosidad, eran vistos por el líder sanjuanino como un impedimento que debía subsanarse para alcanzar esos objetivos. En vez de gauchos, caballos, ganado y ranchos (propios del paisaje pampeano bárbaro), Sarmiento imaginaba inmigrantes, embarcaciones, navegantes intrépidos, industriales laboriosos y ciudades portuarias (para sus paisajes fluviales civilizados) ${ }^{14}$.

La navegación de los cursos de agua del Delta y demás ríos interiores del país fue imaginada profusamente por la mente de este dirigente que, como líder práctico de lo teórico (Sánchez Sorondo, 1977), era consciente del carácter performativo de la palabra. Dada la importancia que las vías navegables tenían en ese entonces en términos de soberanía (el litoral marítimo se entendía como algo alejado), Sarmiento decide crear durante su presidencia la Escuela Naval Militar y los Talleres de la Marina en la localidad de Las Conchas/Tigre a comienzos de la década de 1870, para lo cual encarga buques fluviales a Inglaterra. También el más popular escritor sanjuanino planteaba la necesidad de que los puertos de cabotaje de San Fernando y Tigre, ubicados (casi) sobre el río Luján, tuvieran mejor conexión fluvial con el Paraná de las Palmas, para lo que consideraba imperiosa la construcción de canales que unieran ambos cursos de agua, ahorrándose con ello tiempo y garantizándose la navegación en todo momento. Sarmiento no llegó a ser testigo de la concreción de sus propuestas de canalización en el Delta (fallece en 1888), las cuales recién lograron plasmarse en las primeras décadas del siglo $X{ }^{15}$.

Como es posible advertir hasta aquí, las imágenes literarias e ideas planteadas para las islas del Delta (y demás afluentes del Plata) en las obras de Sarmiento -Argirópolis y El Carapachaydarían cuenta del pasaje de una geografía inmóvil a otra geografía en movimiento. Al igual que en su libro más conocido (Facundo), en las obras señaladas el autor buscó accionar la geografía de las islas del Delta del Paraná a través de la construcción de un nuevo imaginario geográfico (y de la naturaleza) fluvial que, al tiempo que utópico y realista, proyectaba la supresión del vacío civilizatorio heredado de los habitantes prehispánicos, de la colonización española y, sobre todo, de la barbarie presente en los gobiernos de los primeros (y convulsionados) años de vida independiente. Como buen hijo de su tiempo, para Sarmiento era imperiosa la transformación material de los cursos de agua, de las tierras y de la vegetación de las islas del Delta, para lo que se requería de la incorporación de técnicas y de capitales extranjeros, de trabajo y de cultivos (y de la cultura) de la inmigración europea (los criollos, gauchos y lugareños fueron por éste desestimados), im-

14 Cabe señalar que difusión de las islas del Delta realizada por Sarmiento tuvo una rápida acogida por la sociedad, cuadriplicándose la cantidad de habitantes en los años siguientes, muchos de los cuales eran inmigrantes que fueron a probar suerte en las islas; poblamiento que en alguna medida también fue estimulado por la mirada romántica e idealista sobre la naturaleza isleña retratada por Marcos Sastre (fundador del Salón Literario y de la generación del '37) en su libro El Tempe argentino (1858). Debe recordarse que dicho libro tuvo gran difusión en la década de 1860 al convertirse en literatura obligatoria en las escuelas durante el gobierno de Bartolomé Mitre (Ruíz Moreno de Bunge, 2004). 15 La Provincia de Buenos Aires comenzó las obras de canalizaciones en el Delta en los primeros años del siglo XX: el canal n 1 , que une el arroyo Paycarabí con el Estudiante; el canal n², que une el arroyo Felicaria con el Caracoles; luego le siguieron el n³, el n² y el n5. Ya para 1911, la provincia abrió seis canales más, entre los que se encuentra el canal Arias que vinculó los ríos Luján y Paraná de las Palmas (Ruiz Moreno de Bunge, 2004). 
poniéndole a esa naturaleza considerada como subutilizada, que pocos conocían y que se hallaba "a las puertas" de la ciudad de Buenos Aires, nuevas formas de dominación y de orden, a imagen y semejanza del modelo foráneo estadounidense.

A través de las dos obras analizadas, Sarmiento imaginó que -sobre la naturaleza fluvial, móvil, de aporte sedimentario y de riqueza vegetal, perteneciente al conjunto de islas del Delta ubicadas en la confluencia de los ríos Paraná y del Plata- debía implantarse el eje civilizatorio de la nueva nación, de modo que el llamado progreso (necesario para la creación de un mercado nacional) remontaría aguas arriba, formando una red (fluvial) que permitiera incorporar tanto las grandes extensiones territoriales al sistema de comercio internacional como propiciar su poblamiento con inmigrantes europeos. Este conjunto de ideas y proposiciones tornaron al líder sanjuanino en uno de los principales brazos seculares de las ideologías de las elites liberales decimonónicas, tal como lo ha calificado Sánchez Sorondo (1977), cuyas implicancias territoriales han participado de manera significativa en la gestación de una Argentina desequilibrada, injusta y desigual, en la que pareciera que sólo la región fluvial no muy distante de Buenos Aires logró alcanzar un "progreso sin desarrollo", y las elites localizadas en la llamada Zona Norte metropolitana las que más incorporaron "la cultura de lo fluvial", aunque haya quedado circunscripta a su modalidad recreativa.

\section{Controlar el "gigante dormido": el represamiento del río Paraná como proyecto nacional}

A mediados del siglo XX, el paradigma desarrollista encontró sustento en la incorporación del agua y de los ámbitos fluviales a las dinámicas capitalistas (como vía de navegación, medio de irrigación o generación de energía, por ejemplo), acorde a las demandas de aumento en la producción y consumo de bienes que el crecimiento económico requería. El proceso de organización/ordenamiento de los ámbitos fluviales -mediante su transformación- y la incorporación del agua a los circuitos económicos por medio de tecnologías específicas fueron acompañados de construcciones discursivas e imágenes en torno a dichos espacios, a la ciencia, a la ingeniería, y a la tecnología. Todas ellas vinculadas a los ideales de progreso nacional y desarrollo.

En dicho proceso, las represas tuvieron un lugar privilegiado cargado de simbolismo y fantasía: generar energía, irrigar áreas desérticas y controlar inundaciones fueron pilares del proyecto de modernización basado en la dominación de la naturaleza. Junto a ellas, los ingenieros y los cuerpos técnicos se pronunciaron como los héroes de ese proyecto prometeico, imaginándose como aquellos que traían la emancipación a la humanidad a través de la organización tecnológica de la naturaleza (Kaika, 2006). Particularmente, la tríada dominación, naturaleza y emancipación aparecerá frecuentemente en la historia moderna de la ingeniería, constituyendo el fundamento ideológico principal en la mayor parte de las empresas orientadas al represamiento de los cursos fluviales. Fundamento que, enmarcado en un proyecto estatal, va a vincularse muchas veces a la idea de nación o desarrollo nacional. Así, estas obras ingenieriles fueron consideradas parte del orgullo nacional, al tiempo que representaban la realización de su potencial económico, social y cultural (Kaika, 2006).

Durante la segunda mitad del siglo XX, en los países del llamado tercer mundo, los Grandes Proyectos Hidráulicos (GPH) adquirieron gran significancia como motor de las prácticas desa- 
rrollistas. El discurso que acompañó este proyecto de modernización territorial, basado en la industrialización y la urbanización, colocó a estas obras en un lugar relevante. Durante este período, los GPH se constituyeron en artefactos que organizaron tanto las formas de poder como de conocimiento. Así, del lado del desarrollo se posicionaban los expertos, la tecnología y el capital, mientras que del otro, quedaban las poblaciones y las formas de vida locales junto a las producciones culturales tradicionales. Estas formas de vida tradicionales eran, en la visión desarrollista, aquello que debía superarse.

Latta y Sasso (2014) destacan que las grandes represas, en la historia socio-ecológica de los lugares donde se implantan, constituyen "formas especificas en las que se materializan las relaciones sociales que conforman nuestra modernidad capitalista"; por un lado, "constituyen un hecho material-simbólico que reproduce la cosmovisión en que se fundamenta el liderazgo moral y cultural de la elite" y por el otro, implican una "reconstrucción del mundo" que se realiza en la conversión de la naturaleza cruda en materia prima, energía y capital (Latta y Sasso, 2014:72).

Por otra parte, Swyngedouw (2015) ha indicado la complejidad que encierran las obras hidráulicas, considerándolas como nodos de un paisaje hidrosocial, y cuyo objetivo sería convertir la naturaleza en capital, mediante un proceso que implica transformaciones en las relaciones entre sociedad y naturaleza, y a su vez, modificaciones en las jerarquías y relaciones de poder que se dan entre los diversos sectores sociales involucrados en la obra. Es por esto que el autor considera a los GPH como piezas clave de las configuraciones socio-ecológicas. Para Swyngedouw, dichas configuraciones emergen a partir de dinámicas de ensamblaje, des-ensamblaje y re-ensamblaje de procesos humanos y no-humanos que disparan "imaginarios, sueños, fantasías y relaciones político-económicas y de poder" (Swyngedouw, 2015:227). En este sentido, sostiene que el agua (como así también la naturaleza) no existe por fuera de las cadenas metonímicas y de las prácticas sociales que conforman una especie de significado inestable acerca de lo que es el agua y la naturaleza (Swyngedouw, 2011, 2015). Puede considerarse entonces a los GPH como cristalizaciones materiales de específicas relaciones que la sociedad ha entablado con aquello que considera naturaleza, y como vehículos materiales a través de los cuales, dichas relaciones, de construyen y re-construyen. Si una obra hidroeléctrica se representa, en el imaginario del poder, como un artefacto vinculado a las ideas de progreso económico y social -y de hecho, este tipo de artefactos tecnológicos pueden ser efectivamente impulsores de tal crecimiento en este sector social-, por el contrario, puede representar una amenaza para la estabilidad de las sociedades directamente afectadas por las transformaciones socioecológicas y territoriales que implica su construcción. En estos sectores sociales los imaginarios acerca de la obra serán diferentes.

Haciendo esta salvedad, el apartado propone indagar en los discursos y las imágenes -consideradas en sentido amplio- elaboradas en las esferas de poder que promocionaron el PHPM durante los últimos años de la década de 1970. El trabajo se ha enfocado en el análisis de las elaboraciones en torno al emprendimiento que fueron difundidas durante la última dictadura militar ${ }^{16}$ (1976-1981). Fue durante este momento que el proyecto alcanzó mayor desarrollo técnico, a la par de su amplia promoción a nivel social (mayormente en la prensa y en eventos públicos). 
Se ha observado que las elaboraciones imaginarias en torno al proyecto partían de una idea de construcción nacional que se apoyaba en tres nociones estructurantes: el territorio nacional, la infraestructura territorial y los recursos naturales. A nuestro entender, dichas nociones, además de estructurar los discursos en torno al emprendimiento, sustentaron la idea de nación en el imaginario hegemónico. En una alocución pronunciada por el comandante en jefe de las fuerzas armadas durante las Segundas Jornadas El Paraná Medio, el militar expresaba: “La armada ha señalado y señalará hasta que sea una realidad, la necesidad de ocupar los espacios vacíos, de explotar racionalmente nuestros recursos naturales, de acrecentar nuestro patrimonio marítimo y fluvial, por cuanto entiende que así se podrá lograr mayor bienestar para todos los que habitan nuestro suelo y con ello un real y perdurable engrandecimiento para nuestra nación" (Lambruschini, 1979:27). Puede observarse que la articulación entre territorio, recursos naturales e infraestructura se integra a la idea de nación, y específicamente de engrandecimiento nacional. Este engrandecimiento se veía como el correlato de la expulsión de aquello considerado "no civilizado". En palabras del Rector de la Universidad Nacional del Litoral en las mismas jornadas, la necesidad de concretar el proyecto residía en "...fortificar con obras que nos enorgullezcan y afirmen nuestras convicciones occidentalistas, la acción militar para erradicar doctrinas extrañas a nuestra tradición argentina y la integración con el aporte de la civilidad." (Douglas Maldonado, 1979:25).

A su vez, en cada una de las nociones estructurantes se identificaron las imágenes elaboradas en asociación a ellas del siguiente modo: el territorio nacional se imaginaba como resultado de la ocupación del espacio vacío, el PHPM, en tanto artefacto tecnológico-infraestructural se concebía como la palanca de grandeza, y el río Paraná, en tanto recurso natural, se representaba con la imagen del gigante dormido al que era necesario vencer y aprovechar. Lo que se desarrolla a continuación es un análisis de dichas imágenes a partir de una serie de alocuciones realizadas con motivo de las Primeras y Segundas Jornadas Paraná Medio, llevadas a cabo en Paraná (1978) y Santa Fe (1979). Ambos eventos fueron organizados por la Universidad Nacional en las provincias de Entre Ríos y Santa Fe, respectivamente, y tuvieron como objetivo difundir información sobre el proyecto hidroeléctrico a partir de la creación de un espacio de discusión entre miembros del cuerpo militar, algunos políticos que no pertenecían al gobierno en mandato, técnicos de la empresa que llevaba adelante el proyecto (Agua y Energía) e ingenieros de ambas universidades.

\section{Ocupar el "espacio vacío" para construir el territorio}

Como pudo observarse en el primer caso analizado, la imagen del espacio vacío junto a la idea de ocuparlo han construido históricamente buena parte de las narrativas y los discursos, tanto en el proceso de elaboración de una idea de nación (Rodríguez, 2010), como también durante las posteriores acciones de avanzada sobre territorio indígena (Minvielle y Zusman, 1995; Zusman, 2000). Particularmente, los escritos de Sarmiento expresan esa invención del desierto (como espacio vacío), que -puede decirse- funcionó como pantalla de proyección de un imaginario en torno a la construcción del estado-nación. En esta lógica, la nación porvenir se proyectaba en un espacio que se imaginaba necesariamente vacío, o como ha señalado Rodríguez (2010:15), el desierto fue el nombre que se le asignó a "la plenitud ausente de un estado-nación porvenir".

Hacia la segunda mitad del siglo XX, la necesidad de ocupar el espacio vacío ya no se fundaba en construir una nación homogénea y civilizada avanzando sobre el espacio indígena, sino en incorporar áreas específicas del país -bajo la concepción de recursos naturales- al sistema produc- 
tivo. En términos generales, las miradas de los gobiernos desarrollistas y de los sectores sociales encumbrados que acompañaban dicho proyecto, más que espacios vacíos imaginaban recursos ociosos o desperdiciados. El objetivo ya no era la expansión político-territorial, sino económico-territorial sobre determinadas áreas, pretendiendo incorporarlas al régimen de acumulación para impulsar la industria y la urbanización.

Sin embargo, el gobierno dictatorial argentino de finales de la década de 1970 hizo un uso particular y estratégico de la idea de espacio vacío, retomando elementos del discurso y las imágenes difundidas en el período de organización del estado-nación. En palabras del Comandante en Jefe de la Armada: "No hace mucho sostuve la urgente necesidad nacional de ocupar decididamente nuestros espacios vacíos. Con ello se contribuirá en forma real a nuestra grandeza y bienestar, y cumplimentaremos un deber moral histórico..." (Lambruschini, 1979:27). Y sigue: "La geopolítica impuso a la Cuenca del Plata un eje norte-sur por el cual debió haberse ya realizado el desarrollo de la región, la conquista y la incorporación de tierras a la cultura occidental y al mundo cristiano, pero que, lamentablemente, ha sido frenado durante largos años por desencuentros internos." (Lambruschini, 1979:28). Para Lambruschini, el eje norte-sur a lo largo del río Paraná, donde se ubicaría el PHPM, aún constituía un espacio vacío (de política, de religión, de cultura). Dicha ocupación podría alcanzar su realización mediante la concreción de los proyectos en la Cuenca del Plata, consistentes en canalizaciones, hidroeléctricas y puertos. En el discurso del militar, la ocupación del territorio mediante las obras infraestructurales consolidaría una nacionalidad que, hasta ese momento -según él- se había mantenido deficiente: “Este eje norte-sur, no solamente debe ser consolidado, sino que debe ser expandido, afincando intereses que además de ser lícitamente respetables, contribuyan al fortalecimiento de nuestra nacionalidad" (Lambruschini, 1979:28).

Pero esta idea del espacio vacío que es necesario ocupar puede ser comprendida también en el contexto más amplio, del conflicto territorial que Argentina mantenía con Chile desde 1888, así como también en el contexto de conflicto interno que la dictadura mantenía con quienes no adherían a su régimen. Por un lado, el conflicto con Chile llegó a su punto de mayor intensidad en 1978 y consistió en la disputa por la soberanía de algunas islas en el canal de Beagle con el país limítrofe. En 1977 un laudo arbitral había favorecido a Chile, y frente a tal resolución, el gobierno militar argentino decidió rechazar el dictamen y llevar la disputa a una instancia bélica que no se concretó. Por el otro, el conflicto interno se manifestó a través de la persecución que la última dictadura militar perpetró contra sectores sociales disidentes, en un momento de crisis económica, institucional y política.

En este contexto, inventar la imagen de un espacio vacío (equivalente al caos) para ocuparlo, y así impulsar el desarrollo frenado, aparecía como una fórmula que actuaba en tres sentidos: en primer lugar, creaba una imagen de re-fundación de la nacionalidad, o de continuar un proyecto anterior al de los últimos gobiernos. En segundo lugar y de manera indirecta, contribuía a generar un consenso acerca de la legitimidad de la postura que el gobierno militar había tomado respecto del arbitraje con Chile (ocupar se constituía en un acto de afirmación de la soberanía). En tercer lugar, inventaba una pausa en el proceso de desarrollo, el cual el gobierno militar pretendía retomar a través de la instauración de un orden. Esta pausa se concebía como un momento de desorden, y era asignada a los gobiernos precedentes (especialmente el peronismo), con los cuales esta dictadura intentaba antagonizar. 


\section{Controlar el "gigante dormido" para aprovecharlo económicamente}

El manejo instrumental de la naturaleza se encuentra, en el pensamiento moderno, estrechamente vinculado a la idea de dominación. El conocimiento científico, sustentado en la observación y la experimentación, también se concebirá en términos utilitarios. Es decir, que esta racionalidad se va a orientar a una utilidad inmediata, alcanzable mediante procedimientos o artefactos de dominación (o explotación) de aquello que se concibió como naturaleza. Esta última se imaginó -dentro de esta lógica- como la contrapartida de la razón (manifestada en la ciencia y los artefactos técnicos), y por lo tanto se convirtió en aquello que debía vencerse, es decir, dominarse.

En otro orden de ideas, puede afirmarse que la lógica capitalista asume que el proceso de acumulación de riqueza constituye un elemento clave para la permanencia del sistema. Dicha acumulación encuentra realización en los procesos de transformación de la naturaleza. Es decir, la naturaleza adquiere una finalidad utilitaria que se determina por su valor económico potencial. Desde esta correlación de ideas, pueden comprenderse la variedad de imágenes elaboradas sobre distintos elementos pertenecientes al territorio nacional (considerados naturaleza), los cuales por no haber sido transformados -es decir, incorporados al sistema productivo- fueron designados como desperdiciados u ociosos.

En el discurso que promovió el PHPM, el río Paraná adquirió una imagen múltiple, en sintonía con algunas de sus características propias. Este río de llanura posee crecidas periódicas que inundan ampliamente su valle aluvial, y un caudal medido en 16 mil metros cúbicos por segundo. El Paraná ha sido históricamente aprovechado para distintos fines humanos (navegación, agricultura), pero también ha participado en desastres (inundaciones), cuando su valle aluvial ha sido urbanizado. Así, las imágenes asociadas al río se alternan entre aquellas que lo muestran como un benefactor y las contrarias, que lo consideran una amenaza incontrolable.

En el discurso que promovía el PHPM durante la década de 1970, el río Paraná fue concebido en esta tensión beneficio/amenaza a través de la imagen del gigante dormido. Esta imagen remite a una fuerza descomunal amenazante, que puede despertar en cualquier momento e inundar las poblaciones (y por esto se debe controlar): "los grandes ríos de nuestro país son gigantes dormidos de los que nos acordamos cuando crecen desmedidamente y provocan inundaciones y todos los daños subsecuentes" (El Litoral, 30.12.1978), o también:"Ya hemos señalado, por ejemplo, que se podrá regular de tal forma el río Paraná, que sus cíclicas y catastróficas inundaciones pasarán a ser un mal recuerdo" (Editorial de El Diario, 24 de agosto de 1978). Pero también hace referencia a un valor guardado por el gigante al que hay que vencer, y que puede ser aprovechado en términos económicos. En palabras de un representante de Obras Públicas de Entre Ríos: "Pero estas maravillas de ríos que abrazan a nuestra región, eran fuertes torrentes difíciles de vencer y toda solución para unir las márgenes y aprovechar sus cursos, resultaban empresas de envergadura..." (Moia, 1978:21).

Acorde a las ideas que conformaron el imaginario desarrollista (cuyo postulado principal, dijimos, se basaba en que el crecimiento económico se obtenía mediante la explotación humana de los recursos naturales) aparecía la concepción meramente utilitarista del río y la necesidad de darle sentido a través de la transformación humana: "Pero el vencer el río, no era la única meta, no basta la vinculación, existía la urgencia de orientar, dar sentido a ese potencial guardado de sus 
aguas, que nos permitiese utilizar esa energía..." (Moia, 1978:22). No aprovechar el río implicaba un obstáculo para el desarrollo de las poblaciones: "El contar con los caudalosos ríos Paraná y Uruguay, magníficos regalos de la mano de Dios, que debian hacer de estas tierras un privilegio, se convirtieron en un obstáculo, al no poder aprovecharlos ni como vía de comunicación, transporte, ni utilizar sus fuerzas, creando así barreras que por largos años, parecieron infranqueables" (Moia, 1978:21). Por el contrario, su aprovechamiento económico conduciría al desarrollo: "...esa fuerza incontenible del agua guardada por siglos y sin aprovechamiento que nos permitirá el despegue como región y como país..." (Moia, 1978:23).

En otro orden de ideas, se apelaba al sentido bíblico de la naturaleza al servicio del uso humano. Así lo expresaba un representante de la empresa Agua y Energía, quién combinaba en su discurso misión divina con metas económicas: "Por lo tanto, ese recurso energético formidable que nos ha dado Dios, en la naturaleza, ilimitado y renovable, nos indica que debemos aprovecharlo y ahorrar el petróleo al máximo, ya sea el nuestro o el que estamos importando" (Beretta, 1978:35).

\section{El proyecto hidroeléctrico como "palanca de grandeza"}

La razón técnica que ha guiado los procesos de modernización territorial durante el siglo XX en los países de América Latina, se hizo visible principalmente a través del despliegue de infraestructura. Las teorías desarrollistas instaladas en estos países desde mediados de dicho siglo, confiaban en que el crecimiento económico y social se alcanzaría como correlato del proceso de modernización tecnológica. Dicha relación entre prosperidad y salto tecnológico ya era manifestada por el presidente de Estados Unidos, Harry Truman, en su discurso de 1949: "Debemos embarcarnos en un nuevo y audaz programa para hacer que los beneficios de nuestro avance científico y progreso industrial estén disponibles para la mejora y el crecimiento de las áreas subdesarrolladas" (Truman, 1949) ${ }^{17}$.

En dicha lógica, el proceso de modernización se entendía en términos de producción de bienes (mediante la incorporación de tecnología a la industria), como de despliegue de infraestructura (a través de la organización tecnológica de la naturaleza). Según ha señalado Ullrich (2010:308), "con la era del desarrollo, la ciencia y la tecnología tomaron el papel principal. Ambas se consideraban las razones de la superioridad del Norte y la garantía de la promesa desarrollista". Así, para los países considerados en vías del desarrollo, la clave estaba en el avance tecnológico. $Y$ dentro de este esquema, los proyectos hidráulicos tuvieron un rol destacado como parte de un imaginario más amplio que asociaba tecnología, recursos naturales y progreso nacional.

Durante la década de 1970, el PHPM se promovió en el marco de las políticas energéticas del Plan de Desarrollo y Seguridad 1971-1975. Este plan mencionaba entre sus objetivos principales, obtener "crecimiento y autonomía económica y tecnológica" (p.11) así como también el "aprovechamiento de los recursos hídricos" (p.138). En este marco, el emprendimiento hidroeléctrico se concibió a la vez como artefacto con fines técnicos específicos (generación de energía, irrigación, control de inundaciones), y como símbolo de desarrollo regional y nacional. En el discurso de sus promotores, la represa se imaginaba como un punto de inflexión -hacia el desarrollo- en la historia de la región. La imagen utilizada era la de palanca, es decir, un artefacto técnico que, apoyado en 
un punto, vencería una fuerza (la naturaleza) aplicando otra fuerza (la construcción humana). El resultado sería la grandeza: "Aquí sí como dice la Biblia...en el principio era el verbo... Paraná Medio es, para las provincias del litoral, la palanca de su grandeza". (Paganini, 1978:27). Incluso, la acción de esta palanca era comparada con un inicio divino, que en el discurso del funcionario se comparaba con el origen cristiano, acorde con los valores que promovió la dictadura militar de esos años.

En otro orden, la idea de misión en plan de redención universal asignada a la tecnología, se encuentra en las premisas del pensamiento moderno. Como ha sugerido Ullrich (2010:311), "el mito central de la modernidad europea es también un plan de salvación para ser aplicado al mundo entero". Este mito, señala el autor, asume que la constante producción de bienes, la conquista de la naturaleza y la transformación del mundo en algo predecible y manipulable tecnológicamente conducirán automáticamente a la redención y a la felicidad humana. De ahí, que la tarea del estado y del aparato burocrático se considerará una misión excelsa (Hanna y Allouche, 2018). En las palabras de un representante de la Facultad de Ingeniería de Entre Ríos: "Este grupo de ingenieros argentinos demostrará al país y al mundo, el avance logrado por nuestra tecnología, y nuestra capacidad de recursos humanos para enfrentar proyectos análogos de grandes obras de infraestructura" (Díaz Molano, 1978:19). Dicha misión, se imaginaba parte de un destino nacional inexorable, que era el desarrollo: "Proyectos de este tipo significan retomar la confianza en nuestro destino, sobre la base de los enormes recursos que nos prodiga la naturaleza, y aunar esfuerzos para volver a tener confianza en la concreción de obras que el país requiere inmediatamente para impulsar su desarrollo" (Palmeyro, 1978:29).

Sin embargo, esta idea del PHPM como palanca de grandeza debe leerse en el contexto particular de Argentina a finales de la década de 1970, y de la apropiación particular que hizo el gobierno dictatorial de las ideas que conformaron el imaginario en torno al proyecto. Como se mencionó antes, el país arrastraba décadas de discontinuidades institucionales y crisis económicas que no eran propicias para la obtención de créditos internacionales que posibilitaran la concreción de grandes obras. Junto a esto, la inestabilidad económica surgida luego de la crisis del petróleo (1973) se sumaba a dicha condición, a la vez que colocaba la atención en obtener energía de fuentes no fósiles dentro del país.

En tal contexto, el PHPM se promovió como un punto de inflexión hacia la independencia energética y hacia el despegue de la industrialización, idea aún defendida a finales de la década de 1970, por la fracción nacionalista de la última dictadura militar. Independencia energética e industrialización conducirían -según este imaginario- a la grandeza regional y de la nación.

Recapitulando, puede decirse que el PHPM fue promovido como una pieza relevante de reafirmación del ser nacional, tal como lo expresaba el representante del gobierno de Santa Fe, en las Jornadas del Paraná Medio: "Paraná Medio es una obra de absoluta decisión nacional que reafirma la soberanía demostrando ante la humanidad nuestra capacidad para utilizar racionalmente los recursos naturales de que disponemos y concretando con hechos, mediante su concepción y diseño por hombres argentinos, la inquebrantable voluntad de SER a través del único medio posible: la grandeza del país." (Paganini, 1978:27).

De este modo, el objetivo de la integración territorial que se justificaba en la idea de fortalecimiento de soberanía nacional, se alcanzaba a través de la infraestructura hidráulica que operaría como artefacto tecnológico (palanca) de transformación y explotación de los recursos naturales. 


\section{Conclusiones}

Los análisis de los imaginarios geográficos posibilitan el abordaje de las relaciones que se juegan entre las elaboraciones mentales de determinados grupos sociales y los mecanismos específicos que utilizan para la apropiación espacial o la defensa de un territorio considerado como propio. Los casos aquí tratados muestran la importancia estratégica que las elaboraciones imaginarias de los grupos dominantes tuvieron en la construcción de una idea específica de nación, progreso y desarrollo en Argentina durante casi dos siglos, para dos ámbitos fluviales del río Paraná. En el primer momento analizado, las limitaciones en torno al desierto, la barbarie y los obstáculos geográficos en tierra firme, eran superadas en el imaginario geográfico sarmientino a partir de la activación de lo fluvial, la libre circulación del comercio y la incorporación de inmigrantes europeos. La capacidad imaginante del líder sanjuanino encontró en el enmarañado sistema deltaico paranaense material prolífico para fundar tanto la capital de un nuevo arreglo institucional utópico (Argirópolis), como para convertir la naturaleza bruta de las aguas y los suelos de las islas en una California sureña en función del progreso de la nación. De modo análogo, el proyecto desarrollista que constituyó una segunda modernización territorial en Argentina (Silveira, 1999), hizo uso de una serie de imaginarios vinculados a la incorporación de los cursos de agua como un recurso natural que a través de la tecnología conduciría al desarrollo nacional. En particular la dictadura militar que prevaleció desde 1976 hasta 1981 llevó adelante su proyecto de refundación nacional retomando las ideas de desierto y espacio vacío formuladas por las elites liberales decimonónicas.

En ambos proyectos de apropiación territorial, pueden observarse dos cuestiones centrales interrelacionadas: por un lado, el énfasis por parte de los grupos de poder, puesto en la idea de dominar/ordenar una naturaleza virgen de orden fluvial a través del uso de la técnica, el conocimiento científico y los capitales (es decir, aquello asociado con la civilización y la modernidad de su tiempo). Y por otro lado, la idea explícita de imponer un modelo específico de orden social y territorial (que se imponía a la naturaleza), acorde a los objetivos de dichos grupos y que implicaban generalmente la exclusión/desalojo de las tierras, formas de vida y valoraciones de los pueblos allí presentes. Así, en el siglo XIX los objetivos de las elites dominantes estaban puestos en la sustitución de la naturaleza bruta y de las poblaciones nativas heterogéneas por sus modalidades civilizadas y europeizadas. Mientras que en el proyecto dictatorial de la década de 1970, la naturaleza ociosa debía ponerse al servicio de la producción, junto a la imposición de un orden que implicaba avanzar sobre el caos imperante -también imaginado como espacio vacío- asociado tanto a los gobiernos anteriores como a los grupos políticos disidentes. Sobre estos últimos, la dictadura ejerció una brutal persecución; pero también, la imagen del espacio vacío le fue particularmente útil al gobierno para la justificación de las relaciones conflictivas que el mismo mantuvo con los países limítrofes.

Asimismo, y a pesar de que ninguno de los proyectos fue concretado, la importancia estratégica de las construcciones imaginarias que los mismos han vehiculizado, puede observarse en su permanencia a través del tiempo, como orientadoras de posteriores iniciativas: por ejemplo, en el "Proyecto Estratégico para el delta del Paraná Bajo y Medio" derivado de un acuerdo entre el Ministerio de Interior, Obras Públicas y Vivienda de la República Argentina y el Ministerio de Infraestructura y Gestión Hídrica de los Reinos de los Países Bajos en 2017, se vuelve a proponer un modelo de desarrollo fundado en la construcción de infraestructuras viales e hidráulicas (canalizaciones, mejoras en las existentes, etc.), y en la creación de asentamientos urbanos estables 
para determinados sectores de las islas; no cabe duda que estas propuestas se referencian en alguna medida en la ideas trazadas para esos territorios fluviales por parte de Sarmiento hace más de 170 años. En el caso del PHPM, continúa siendo considerado un norte a alcanzar -asociado al desarrollo de la región- en los círculos y oficinas de ingenieros y técnicos (principalmente en la provincia de Santa Fe); y ha sufrido re-elaboraciones en adecuación, tanto a las tecnologías disponibles del nuevo siglo, como a las necesidades de libre circulación de la Hidrovía Paraguay-Paraná (donde se encuentra emplazado el proyecto).

\section{Bibliografía}

ABOITES AGUILAR, L. El agua para la nación. Una historia política de México (1888-1946). México: CIESAS, 1999.

AGUDELO, P. (Des) hilvanar el sentido/los juegos de Penélope. Una revisión del concepto imaginario y sus implicancias sociales. Uni/Pluri Versidad, 2011, vol. 11, № 3, p. 1-18.

ALBERDI, J. B. Bases y puntos de partida para la organización política de la República Argentina. Buenos Aires: Biblioteca del Congreso de la Nación, 2017, $1^{\circ}$ edición.

AMARO CASTRO, L. La América reinventada. Notas sobre la utopía de la "civilización" Argirópolis, de Domingo Faustino Sarmiento. Espéculo. Revista de Estudios Literarios, 2003, № 25. Disponible en: http p.//www.ucm.es/info/especulo/numero25/argiropo.html

BACHELARD, G. La poética del espacio. México: Fondo de Cultura Económica, 1965.

BERETTA, M. Descripción general. En: UNIVERSIDAD NACIONAL DE ENTRE RÍOS. Primeras Jornadas El Paraná Medio. Entre Ríos: UNER, 1978, p. 33-51.

BHABHA, H. Narrando la nación. En: FERNÁNDEZ BRAVO, A. (comp.). La invención de la nación. Lecturas de la identidad de Herder a Homi Bhabha. Buenos Aires: Manantial, 2000, p. 211-222.

BOTANA, N. Prólogo. En: SARMIENTO, D. Argirópolis, Buenos Aires: EMECÉ, 2011, p. 13-31.

CANELO, P. (2016) La política secreta de la última dictadura argentina (1976-1983). Buenos Aires: Edhasa.

CASTORIADIS, C. La institución imaginaria de la sociedad. Buenos Aires: Tusquets, Colección Ensayo, 2007.

CASTREE, N. Making Sense of Nature. Representation, politics and democracy. London \& New York: Routledge, 2014.

DEBARBIEUX, B. Los imaginarios de la naturaleza. En: HIERNAUX, D. y LINDÓN, A. Geografías de lo imaginario. Barcelona y México: Anthropos/UAM, 2012, p. 140-156. 
DÍAZ MOLANO, E. Palabras de Bienvenida, por el Delegado del Rector a cargo de la Facultad de Ingeniería. En: UNIVERSIDAD NACIONAL DE ENTRE RíOS. Primeras Jornadas El Paraná Medio. Entre Ríos: UNER, 1978, p. 17-19.

DURAND, G. Las estructuras antropológicas de lo imaginario. Madrid: Taurus, 1981.

DOUGLAS MALDONADO, J. Discurso del señor rector de la Universidad Nacional del Litoral y presidente de las segundas Jornadas del Paraná Medio. En UNIVERSIDAD NACIONAL DEL LITORAL. Segundas Jornadas El Paraná Medio. Santa Fe: UNL, 1979, p. 23-25.

FERNÁNDEZ BRAVO, A. Introducción a La invención de la nación. Lecturas de la identidad de Herder a Homi Bhabha. Buenos Aires: Manantial, 2000, p. 11-23.

FINCH, R. The Story of the New York State Canals. Historical and Commercial Information, New York: State Engineer and Surveyor, State of New York, 1925.

HANNA, R.; ALLOUCHE, J. Water nationalism in Egypt. State-building, nation-making and Nile hydropolitics. En: MENGA, F. y SWYNGEDOUW, E. Water, Technology and the Nation-State. London \& New York: Earthscan, 2018, p. 81-95.

HIERNAUX, D. Los imaginarios urbanos: de la teoría y los aterrizajes en los estudios urbanos. Eure, 2007, vol. 23, No 99; p. 17-30.

HIERNAUX, D. y LINDÓN, A. Imaginarios urbanos desde América Latina: tradiciones y nuevas perspectivas. En: SILVA, A. (eds.). Imaginarios urbanos en América Latina: Archivos. Barcelona: Fundación Antoni Tapies, 2007, p. 157-167.

HIERNAUX, D. y LINDÓN, A. Renovadas intersecciones: la espacialidad y los imaginarios. En: HIERNAUX, D. y LINDÓN, A. Geografías de lo imaginario. Barcelona y México: Anthropos/UAM, 2012, p. 9-28.

KAIKA, M. Dams as symbols of modernization: the urbanization of nature between geographical imagination and materiality. Annals of the Association of American Geographers, 2006, vol. 96, No 2; p. 276-301.

LAMBRUSCHINI, A. 1979. Alocución del señor miembro de la Junta Militar y Comandante en Jefe de la Armadas. En: UNIVERSIDAD NACIONAL DEL LITORAL. Segundas Jornadas El Paraná Medio. Santa Fe: UNL, 1979, p. 27-34.

LATTA, A. y SASSO, J. Megaproyectos hídricos y conflicto socio-ambiental en Latinoamérica: perspectivas teóricas desde Gramci y Foucault. Agua y Territorio, 2014, Nº 4, p. 70-83.

LINDÓN, A. Los imaginarios urbanos y el constructivismo geográfico: los hologramas espaciales. Eure, 2007, vol. 23, No 99, p. 31-46. 
LOSADA, L. La elite social argentina: visión en perspectiva sobre sus orígenes y formación, 17701910. En: Actas de la $2^{a}$ Reunión internacional sobre formación de las elites. Familia, sociabilidad y procesos de distinción en el acceso a posiciones de elite, 2016, p. 184-204.

MINVIELLE, S. y ZUSMAN, P. Someter al indígena para fundar la Nación. Aproximación a los argumentos que sustentaron la política de organización de colonias indígenas en el siglo pasado. Encuentro de Investigación Social, 1995, Tucumán, Argentina.

MOIA, A. Discurso inaugural por el Ing. Angel Luis Moia, Ministro Interino de obras Públicas de la Provincia de Entre Ríos. En: UNIVERSIDAD NACIONAL DE ENTRE RíOS. Primeras Jornadas El Paraná Medio. Entre Ríos: UNER, 1978, p. 20-23.

MONDADA, L. Espacio y lenguaje. En: LINDÓN, A.; HIERNAUX, D. Tratado de Geografía Humana. Barcelona y México: Anthropos/UAM, 2006, p. 433-459.

MORAES, A. O Sertão. Um "outro" geográfico, Terra Brasilis, 2003, 3/4, 1-8.

PAGANINI, C. Alocución del representante del Gobierno de Santa Fe, contador Carlos Alberto Paganini, Secretario General del COPRODE. En: UNIVERSIDAD NACIONAL DE ENTRE RÍOS. Primeras Jornadas El Paraná Medio. Entre Ríos: UNER, 1978, p. 24-27.

PALMEYRO, J. Discurso pronunciado por el Agrimensor Julio Jorge Palmeyro, Secretario de Estado de Obras y Servicios Públicos en representación del Gobierno de Corrientes. En: UNIVERSIDAD NACIONAL DE ENTRE RíOS. Primeras Jornadas El Paraná Medio. Entre Ríos: UNER, 1978, p. 28-29.

PAREKH, B. El etnocentrismo del discurso nacionalista. En: FERNÁNDEZ BRAVO, A. (comp.). La invención de la nación. Lecturas de la identidad de Herder a Homi Bhabha. Buenos Aires: Manantial, 2000, p. 91-122.

PICKENHAYN, J. Trama geográfica en las utopías de Sarmiento, Scripta Nova. Revista electrónica de Geografía y Ciencias Sociales, 2000, № 62. Disponible en: https://www.ub.es/geocrit/sn-62. htm.

RODRÍGUEZ, F. Un desierto para la nación. La escritura del vacío. Buenos Aires: Eterna Cadencia, 2010.

RUIZ MORENO DE BUNGE, S. Tigre y las verdes islas del Delta. Buenos Aires: El Autor, 2004.

SÁNCHEZ SORONDO, M. Sarmiento, un hombre de acción. SUR, 1977, N³ 341, p. 136-155. Buenos Aires.

SARMIENTO, D. El Carapachay. Buenos Aires: EUDEBA, 1974.

SARMIENTO, D. Argirópolis, Buenos Aires: EMECÉ, 2011, 1 edición. 
SERJE, M. Regiones invisibles: la producción de las últimas fronteras. En: NÚÑEZ. A. et al (eds.). Imaginarios geográficos, prácticas y discursos de frontera. Aisén-Patagonia desde el texto de la Nación. Santiago de Chile: Serie Geolibros/Ñire Negro, 2017, p. 13-19.

SILVEIRA, M.L. Un país, uma região. Fim de século e modernidades na Argentina. Sao Paulo:

FAPESP/LABOPLAN-USP, 1999.

SILVESTRI, G. El color del río. Historia cultural del paisaje del Riachuelo. Bernal: Universidad Nacional de Quilmes, 2003.

SMITH, N. Uneven Development. Nature, Capital and the Production of Space. Great Britain: Blackwell, 1990.

SWYNGEDOUW, E. La Naturaleza no existe! La sostenibiliad como síntoma de una planificación despolitizada. Urban, 2011, No 1, p. 41-66.

SWYNGEDOUW, E. Liquid Power. Contested Hydro-Modernities in Twentieth-Century Spain. Cambridge, London: The MIT Press, 2015.

TRUMAN, H. Inaugural Address. Washington DC, 20 de Enero de 1949. Disponible en: https://www. trumanlibrary.org/whistlestop/50yr_archive/inagural20jan1949.htm.

ULLRICH, O. Technology. En: SACHS, W. The Development Dictionary. A Guide to Knowledge as Power. London \& New York: Zed Books, 2010, p. 308-322.

WORSTER, D. The Flow of Empire. Comparing Water Control in China and the United States. Rachel Carson Center Perspectives, 2011/5, p. 1-28.

ZUSMAN, P. Desierto, civilización, progreso. La Geografía del Gran Chaco y el proyecto político territorial de la formación del Estado argentino. Eria, 2000, No 51, p. 60-67.

ZUSMAN, P. Paisajes en movimiento. El viaje de Sarmiento a los Estados Unidos (1847). En: VIII Coloquio Internacional de Geocrítica Geografía histórica e historia del territorio, México DF, 2006, p. 1-13.

ZUSMAN, P. La geografía histórica, la imaginación y los imaginarios geográficos. Revista de Geografía Norte Grande, 2013, № 54, p. 51-66.

ZUSMAN, P. Carlos Antonio Robert Moraes (1954-2015): movilidad y formación colonial. Revista Transporte y Territorio, 2015, No 13, p. 227-239. 
